\title{
Microglial Function across the Spectrum of Age and Gender
}

\author{
Jillian C. Nissen \\ Department of Pharmacological Sciences, Stony Brook University, NY 11794-8651, USA; \\ jillian.nissen@stonybrook.edu; Tel.: +1-631-444-3055 \\ Academic Editor: Kurt A. Jellinger \\ Received: 1 February 2017; Accepted: 1 March 2017; Published: 4 March 2017
}

\begin{abstract}
Microglia constitute the resident immunocompetent cells of the central nervous system. Although much work has focused on their ability to mount an inflammatory response in reaction to pathology, recent studies have delved into their role in maintaining homeostasis in the healthy brain. It is important to note that the function of these cells is more complex than originally conceived, as there is increasing evidence that microglial responses can vary greatly among individuals. Here, this review will describe the changing behavior of microglia from development and birth through to the aged brain. Further, it is not only age that impacts the state of the neuroimmune milieu, as microglia have been shown to play a central role in the sexual differentiation of the brain. Finally, this review will discuss the implications this has for the differences in the incidence of neurodegenerative disorders between males and females, and between the young and old.
\end{abstract}

Keywords: microglia; aging; gender; neurodegeneration; Alzheimer's disease

\section{Introduction}

Microglia are a distinct class of glial cells that are critical in mediating the innate and adaptive immune responses of the brain and spinal cord. They are the resident macrophage-like immune cells of the central nervous system (CNS), and are involved in processes essential for development and maintenance of neural homeostasis, managing injury, and subsequent repair [1]. Due to their morphology, microglial cells are described as being in a "resting" state under healthy conditions. This term is somewhat misleading, since in vivo imaging has revealed that microglia actively scavenge and monitor their CNS microenvironment with long, ramified processes for pathogens and damage [2]. These highly motile processes ensure that microglia can rapidly respond to any local disturbances; it is estimated that microglia can survey the entire brain parenchyma within one hour [3]. As microglia express major histocompatibility complex type II (MHC II) proteins, they represent immature antigen presenting cells when in the resting state [4]. Outside of their roles as immunocompetent cells, microglia are intimately involved in modulating synaptic plasticity, as they not only monitor synapses [5], but are responsible for the vital developmental process of synaptic pruning [6,7].

Microglial inflammatory responses to CNS pathologies have been extensively explored in the literature over the years. However, what has not been clearly elucidated is why there is a disparity in the prevalence of these neurodegenerative disorders among the young and the aged, and between men and women. Increasing evidence indicates that the reason for this difference may lie in variations of homeostatic microglial function between genders and during aging. Despite this, prior to the past decade, understanding of the role of microglia in the healthy brain was largely neglected. In this review, we discuss recent findings analyzing microglial behavior across the spectrum of age and gender, and the implications this has regarding the risk of developing neurodegenerative disease. 


\section{Microglial Changes throughout Aging}

\subsection{Microglia in the Developing Brain}

Although microglia are physiologically and functionally very similar to mononuclear phagocytes, including macrophages, dendritic cells, and monocytes, they cannot be considered the exact CNS equivalent of these cells. Mononuclear phagocytes, which give rise to peripheral tissue-specific macrophages, are derived from the bone marrow [8]. As microglia and macrophages share a large number of common markers [9], it was originally considered that they came from the same source. It was later shown that microglia are derived from a primitive macrophage population produced by the yolk sac, and primarily colonize the brain prior to birth beginning at approximately Embryonic Day 8.5 in mice [10,11]. Infiltration of the CNS by microglia is dependent on the establishment of the brain vasculature, and relies on an active blood circulation [11]. It is due to this connection that it was posited that microglia were involved in angiogenesis, and it has indeed been shown that microglial depletion results in sparser distribution of vessels [12,13], and that soluble factors released from microglia are responsible for vessel branching [14]. These cells ultimately develop a heterogeneous morphological phenotype dependent on their location within the brain and their distance from the vasculature. In highly perfused areas, microglia adopt a more complex, ramified morphology [15], while conditions that diminish blood flow delay this process and result in more ameboid cells [16]. Under physiological conditions, microglia proliferate during embryogenesis and locally self-renew thereafter without significant contributions from the bone marrow [17,18].

The fact that microglia are present in the neonatal brain so early in development means that microglia mature alongside neurons, which supports the idea that microglia are crucial mediators of CNS wiring. Local circuit refinement through the selective removal of axon branches and synapses is known as pruning [19]; one of the most well-established facets of microglial functionality in the developing brain. Synapses form as a result of sensory input, and thus in the early postnatal days microglia can be seen to associate with synapses, with a subsequent loss of dendritic spines [20]. Microglia have been shown to actively phagocytose inappropriate synaptic connections, an activity that is critical in modeling the neural network $[6,7,21]$. Several mechanisms have been proposed to explain this function. One focused on the role of the classical complement pathway, as $\mathrm{C} 1 \mathrm{q}$ localizes to developing synapses and can mark these synapses for phagocytosis by microglia in a C3-dependent manner [22]. C1q-null mice exhibited signs of epilepsy as well as enhanced synaptic connectivity, suggesting insufficient pruning by microglia [23]. Another potential mechanism could be through modulation of levels of synaptic adhesion molecules. Tissue plasminogen activator released by microglia has been implicated in reducing the levels of these adhesion molecules, which are essential for synaptic activity and stability [6]. The presence of microglia has also been associated with impaired axonal outgrowth, as their activation with lipopolysaccharide (LPS) resulted in diminished axonal extensions during development, while microglial depletion promoted the reverse [24]. Thus, it is evident that microglia play a critical role in the architecture of the developing brain.

\subsection{Microglia in the Adult Brain}

In the adult CNS, microglia comprise approximately $10 \%-15 \%$ of total cells, with slight variations across brain regions [25]. Once established, the microglial population is maintained by local self-renewal rather than through differentiation of infiltrating monocytes. Although both macrophages and microglia express colony stimulating factor 1 receptor (CSF1R), disruption of signaling through this receptor in mice leads to $\sim 99 \%$ depletion of microglia while it merely diminishes macrophage numbers $[18,26,27]$. Microglial processes are highly dynamic in adult mice, and it is estimated that they could survey the entire brain parenchyma within one hour [28]. In the absence of pathologies, microglia tend to have long, ramified extensions, although these are found to be shorter and thicker in regions that lack a blood-brain barrier (BBB) $[29,30]$. 
It has long been discussed that upon encountering infection or injury, microglia undergo a process known as "activation". This term is somewhat disingenuous as it implies that microglia are inactive in the healthy brain, and only become functional upon encountering perturbations to CNS homeostasis. Rather than considering microglia "resting," it is more accurate to picture them as in a "surveying" state before adopting a reactive, "activated" phenotype. These changes can occur rapidly within minutes of encountering harmful stimuli, upon which they obtain a more amoeboid shape and proliferate [31,32]. This results in the upregulation of major histocompatibility complex (MHC) II, which allows for further recruitment of other inflammatory cells such as neutrophils, lymphocytes, and monocytes into the injury site [33]. Activated microglia can release tumor necrosis factor alpha (TNF $\alpha$ ) and nitric oxide (NO), which promote neurodegeneration [34]. However, microglia also produce anti-inflammatory cytokines such as transforming growth factor beta (TGF $\beta$ ) and interleukin 10 (IL-10), which are neuroprotective and support recovery following injury [35].

As is the case for any immune cell, an essential function of microglia is to be able to distinguish between targets to destroy and healthy cells to protect [25]. In the periphery, the presence of adaptive immune cells allows for a tailored response to a specific threat [36], but there is limited infiltration of helper T cells into the CNS. However, microglia have been shown to function as antigen presenting cells in multiple sclerosis [37]. The primary mechanism by which microglia respond to pathogens or injury is through pattern recognition receptors (PRRs), or soluble mediators released from degenerating neurons. Microglia express toll-like receptors (TLRs) 1-9 [38], and scavenger receptors to detect the presence of intracellular phosphatidylserine (PS) on the extracellular membrane of dying cells [39]. These different TLRs allow microglia to respond differently depending on the particular receptors expressed. For example, TLR4 interacts with bacterial cell wall components such as lipopolysaccharide, which promotes a strong inflammatory response by microglia [40]. TLR4, in concert with TLR2, can sense damage induced by ischemia and develop a response in microglia that results in larger infarct size [41,42]. TLR4 can also detect the release of heat shock protein (HSP) 60 from dying cells within the CNS, creating a positive feedback loop as inflammation among microglial cells promotes further neurodegeneration [43].

Aside from HSPs, dying neurons release a plethora of factors such as cytokines, chemokines, and nucleotides which recruit microglia to the injured area [44]. CCL2, also known as monocyte chemoattractant protein 1 (MCP1), is enriched in injured areas of the CNS. This protein is a chemokine that rapidly recruits microglia through binding to its cognate receptor CCR2 [45]. Disruption of CCL2-CCR2 signaling results in reduced hematoma volume in an animal model of intracerebral hemorrhage [46], and attenuates microglial migration and activation following excitotoxic injury [47]. One of the strongest signals between dying neurons and microglia is adenosine triphosphate (ATP), which can promote phagocytic activity and process extension in microglia [48]. ATP binds to purinergic receptors, of which microglia express seven variants [49]. The numbers of these receptors increase during aging, and are expressed in a sexually dimorphic manner dependent on subtype [50]. Activation of these receptors can be either deleterious or beneficial, as activation of the $P 2 X_{7} R$ variant on microglia promotes the release of inflammatory factors such as IL-1 $\alpha / \beta$ [51], TNF $\alpha$ [52], and superoxide [53], but has also been shown to protect neurons against excitotoxicity resulting from glutamate exposure [54]. In the adult brain, microglia constantly survey for disruptions to homeostasis, and rapidly respond through induction of the inflammatory cascade, serving as the resident professional immune cell of the CNS.

\subsection{Microglia in the Aged Brain}

During aging, there is a wide variety of physiological changes that occur in the CNS. Brain weight decreases around $2 \%-3 \%$ each decade following the age of 50 , and accelerates to a loss of about $10 \%$ in individuals over 80 compared with young adults [55]. In general, during the aging process, the immune system shifts to a chronic mild inflammatory state, with increased levels of pro-inflammatory TNF $\alpha$ and IL-1 $\beta$ in the CNS, and systemic increase of IL-6 [56,57], along with a concomitant decrease of the 
anti-inflammatory cytokine IL-10 [57]. Correlations of cytokine levels to cognitive ability have been inconclusive, but there is some evidence that very high levels of IL-6 could be related to a higher risk of cognitive decline [58]. As microglia are the specialized immune cells of the CNS, these impairments may reflect an alteration in their normal functions. CNS cells undergo a wide variety of genetic and functional changes during aging, as they show a gradual accumulation of DNA damage and oxidative stress over time [59]. This is particularly notable in microglia, as these cells are long-lived and not readily replaced by cells from the periphery [17]. As discussed above, since microglia are so intimately involved in maintaining the connectivity and health of the CNS in homeostatic conditions, any disruption of normal microglial function could have major impacts on the condition of the brain.

In young humans and animals, microglia in the healthy CNS are distributed evenly throughout the neural parenchyma, providing complete coverage of the entire brain and spinal cord. However, during aging, microglia have been seen to increase in both number and density in particular CNS compartments, including the visual and auditory cortices, hippocampus, and retina [60-62]. Why this accumulation occurs is poorly understood, although several hypotheses have been put forward. One suggests that it may be a compensatory mechanism for declining microglial function during aging [63], while others theorize that it may be due to failure of microglial numbers to completely revert back to basal levels after a lifetime of injuries, infections, and other damage [17]. However, these hypotheses still do not account for the preferential accumulation in specific site. They also undergo significant morphological changes, as aged microglia have smaller dendritic arbors, are more elongated, and are less circularly symmetric $[62,64]$. In humans, increased numbers of dystrophic microglia with processes that become fragmented and lose fine branches, are unusually tortuous, and are characterized by bulbous swellings appear during aging [56]. Using live cell imaging of mouse retinal microglia, it was shown that aged cells have slower process motility and reduced response to ATP. Notably, in response to a laser-induced injury aged microglia were both slower to migrate to the injury site and also resided there longer following recovery, supporting the above hypotheses for microglial accumulation [61].

Microglia in aging brains upregulate a variety of "activation" markers, including MHC II, CD86, and PRRs including TLRs and nucleotide-binding oligomerization domain-like (NOD)-like receptors $[65,66]$. Levels of pro-inflammatory cytokines are increased as well, such as IL-1 $\beta$, TNF $\alpha$, and IL-6 $[67,68]$. Observations of these alterations has led to the idea that microglia become sensitized, or "primed" as aging progresses [69]. In fact, aged microglial responsiveness to peripheral signals and the local environment is exacerbated compared to young controls. When aged mice received an intraperitoneal injection of LPS at a dose that results in an acute mild sickness in young mice, their induced IL-1 $\beta$ production was significantly increased [70]. Aged mice also exhibit increased hippocampal microglial numbers following LPS injection compared to their young counterparts [71]. In parallel to the fact that aged microglia tend to linger in injury sites [61], aging rats injected with Escherichia coli have increased hippocampal IL-1 $\beta$ protein levels that remain high for longer than young rats [72]. Interestingly, aged mice expressed higher levels of IL-10 than young mice [64]. IL-10 is an anti-inflammatory cytokine that regulates the production of IL-1 $\beta$, so it is possible that aged mice lose responsiveness to IL-10. The shift of microglia to a more sensitized, "primed" state could imply that these cells would respond much more rapidly and to a greater degree to a secondary stimulus. Thus, as the brain ages, microglia become more reactive, more inflammatory, and increasingly dystrophic, while showing resistance to anti-inflammatory signals. Microglial changes throughout aging are summarized in Figure 1. 


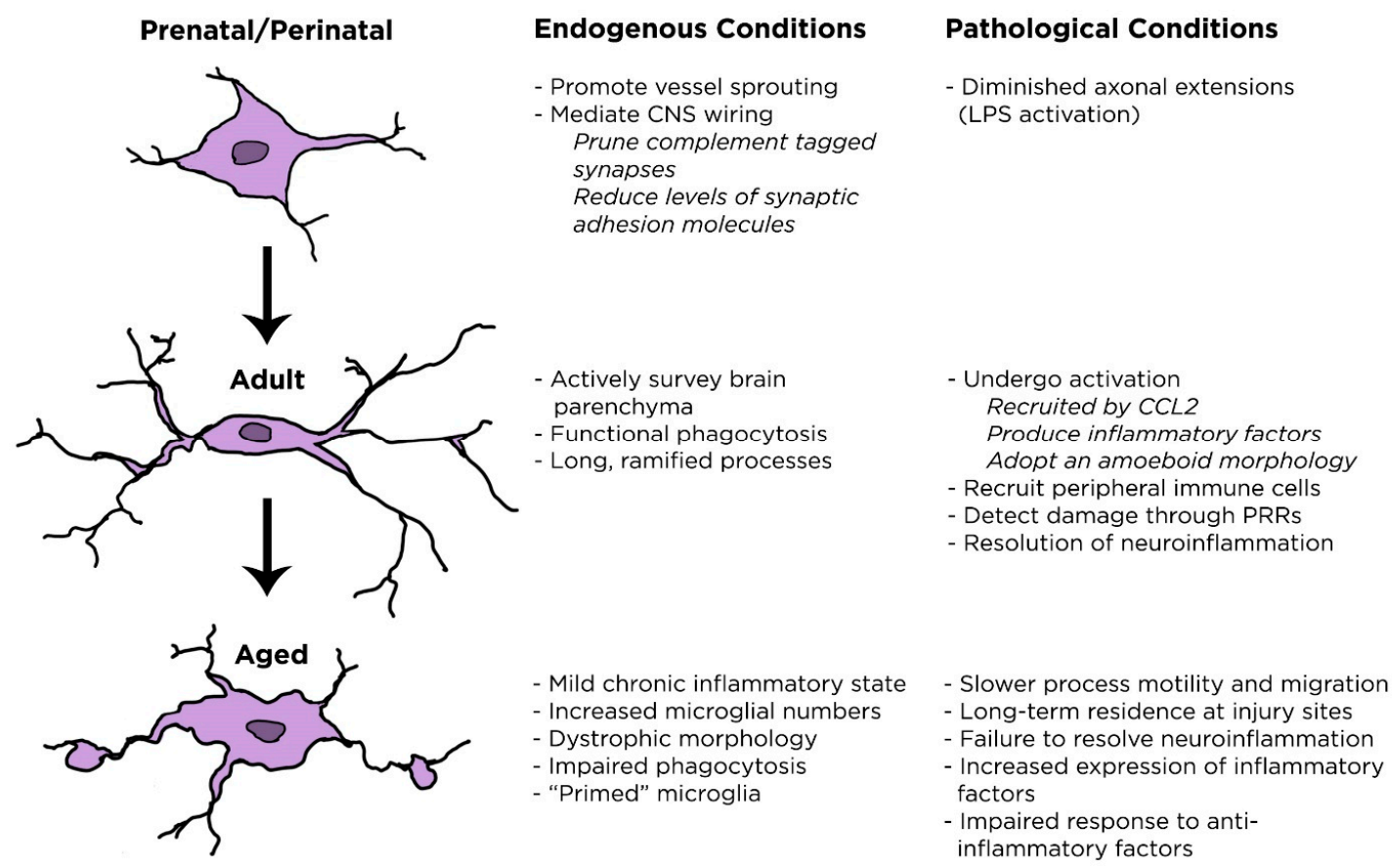

Figure 1. Age-related changes in morphology and function of microglial cells. CNS, central nervous system; LPS, lipopolysaccharide.

\section{Microglial Differences between Genders}

\subsection{Sexual Differentiation of the Brain}

Sex determination in mammals is defined by the presence of the $\mathrm{Y}$ chromosome gene Sry, which is obligatory for proper development of the testes through coding of the testis determining factor. In the absence of this gene, regardless of how much else of the $\mathrm{Y}$ chromosome is present, the gonads instead develop into ovaries [73]. Following this process of sex determination, which is defined by the generation of sex-specific gonads, sex differentiation in other tissues occurs.

The fetal gonad develops early during gestation, and in primates androgen production is evident by the end of the first trimester [74]. Following entry into the brain, testosterone can be processed into either estradiol or dihydrotestosterone (DHT). Testosterone is essential in masculinizing the brain, as exposure of female guinea pigs to testosterone in utero permanently disrupted their ability to display female reproductive behaviors. However, there is a critical period for this modulation, as exposure to testosterone in adulthood does little to affect these behaviors [75]. Estradiol, which is a masculinizing hormone during development in rodents, could potentially be responsible for mediating some of the gross anatomical differences in male and female brains. This hormone is capable of promoting neurite outgrowth in organotypic explant cultures from the preoptic area, hypothalamus, and cerebral cortex [76]. The preoptic area (POA), a major brain region involved in male sexual behavior [77], exhibits a density of dendritic spine synapses in males that are twice as abundant as found in females [78]. This brain region is ultimately 5-7 times larger in males than in females at maturity [79]. Transgenic animals with XX chromosomes that developed testes through incorporation of the Sry gene on autosomes (XX-males) had similar neuroanatomical brain structures and social behaviors to wild-type $X Y$ males, and showed significant differences to wild-type $X X$ females [80]. This result indicates that the presence of the gonads, and by proxy sex-associated hormones, is responsible for sexual differentiation of brain configuration. However, using the same mouse model it was found that $\mathrm{XY}$-males were more aggressive than $\mathrm{XX}$-males, and $\mathrm{XX}$-females showed stronger parenting behaviors than XY-females (animals with Sry deleted from their Y chromosome) [81], demonstrating that hormone effects could not explain the entirety of neural sexual dimorphism. 
Of note is that the $\mathrm{X}$ chromosome has the highest concentration of immune-related genes throughout the entire genome, which could potentially explain why certain autoimmune disorders are so prevalent in females [82]. Multiple sclerosis, a CNS autoimmune disorder which is diagnosed in women over men at a 3:1 ratio [83], has been investigated through an animal model known as experimental autoimmune encephalomyeltitis (EAE). This female prevalence has been supported by studies that show that gonadectomized XX-mice of both genders show greater deficits in EAE than gonadectomized XY-mice [84]. As microglia are the primary immune cell of the CNS, it leads to the question of whether these cells are sexually dimorphic in their function as well.

\subsection{Gender Differences in Microglial Function}

Microglia are found in an activated state in the early postnatal period, and return to a resting state by the third week following birth $[21,85]$. By Postnatal Day 4 , males have greater numbers of amoeboid microglia in the hippocampus, amygdala, and cortex in comparison to females, which diminishes by adolescence [85]. This window corresponds to the "critical period" of hormonally-mediated sexual differentiation of the brain, as an androgen surge results in increased levels of estradiol in the brain that results in masculinization in males [75]. A critical mediator of this masculinization process is prostaglandin E2 (PGE2), which is downstream of estradiol signaling in the POA [86]. PGE2 promotes the formation and stabilization of dendritic synapses, which results in the larger POA seen in males [87]. Microglia in the male POA produce more PGE2 than those in females, and if females are treated with PGE2 this can masculinize their brain [88]. Further, microglial activation is necessary for development of the male features of the POA, as treatment with minocycline, a microglial inhibitor, disrupts the ability of estradiol to promote a male phenotype in dendritic spine numbers [88]. Beyond this correlation, increasing evidence has shown that it is not just microglial numbers that are not comparable between males and females, but that their activity and signaling differ as well.

Primary microglia extracted from the whole brain of female mice at Postnatal Day 3 have higher expression levels of the inflammatory cytokines TNF $\alpha$, IL-1 $\beta$, and IL- 6 compared to males, but this disparity was resolved by Postnatal Day 21 [89]. Again, this timing correlates to the critical period of hormonal expression for brain sex differentiation. There are also variation in purinergic receptors between male and female microglia, as in the early postnatal period males express lower levels of $\mathrm{P}_{2} \mathrm{X}_{4}$ and $\mathrm{P}_{2} \mathrm{Y}_{4}$ receptors [50]. Purinergic receptors are generally associated with microglial activation, and loss of this signaling can disrupt the transition from a quiescent to an inflammatory phenotype [90]. These differences are also recapitulated in injury models, as cortical lesion sites are predominated by either resting or anti-inflammatory microglia in males, while the opposite is the case for females [91]. Taken together, it is suggested by these data that the neuroimmune milieu in females is more inflammatory than males in both the healthy and injured states.

\subsection{Hormonal Regulation of Neuroimmune Function}

Many of these variations between male and female microglia could potentially be explained by differential signaling by steroid hormones, for which microglia express receptors. Several studies have demonstrated the expression of one or both estrogen receptor (ER) subtypes, ER $\alpha$ and ER $\beta$, on microglial cells $[92,93]$. ER $\beta$, which has had conflicting reports regarding its expression on microglial cells $[93,94]$, was found to be highly expressed on the BV-2 microglial cell line, more so than on the N9 microglial cell line [92]. The original source of N9 cells was male mice, and BV-2 cells from females, so it is conceivable that this variant of the estrogen receptor may be enriched in females [95]. At three and seven weeks of age, microglia isolated from male cortices expressed higher levels of ER $\alpha$ than females [96].

Hormones greatly influence microglial function, as treatment of rat microglial cells with $17 \beta$-estradiol, the major female sex steroid following development, results in an inhibition of phagocytosis and diminished levels of reactive oxygen species (ROS) production, inducible nitric oxide synthase (iNOS) expression, and PGE2 release [94]. Interestingly, estradiol has a sexually dimorphic effect on IL-1 $\beta$ production. Culturing male microglia in the presence of estradiol has 
an anti-inflammatory effect, as this significantly reduces their IL-1 $\beta$ production. Surprisingly, estradiol produces an inflammatory response in female microglia instead. This was further supported through the observation that female rats supplemented with estradiol in vivo produced a potentiated IL-1 $\beta$ response among microglial cells compared to males. [97]. It is not yet understood if the prevalence of ER $\alpha$ in males and ER $\beta$ in females contributes to this disparate response. These data correlate to observations discussed above, as it demonstrates that hormonal signaling further promotes the inflammatory response in female microglia while exerting an anti-inflammatory effect on those in males. Sexual dimorphism of microglial function is summarized in Figure 2.

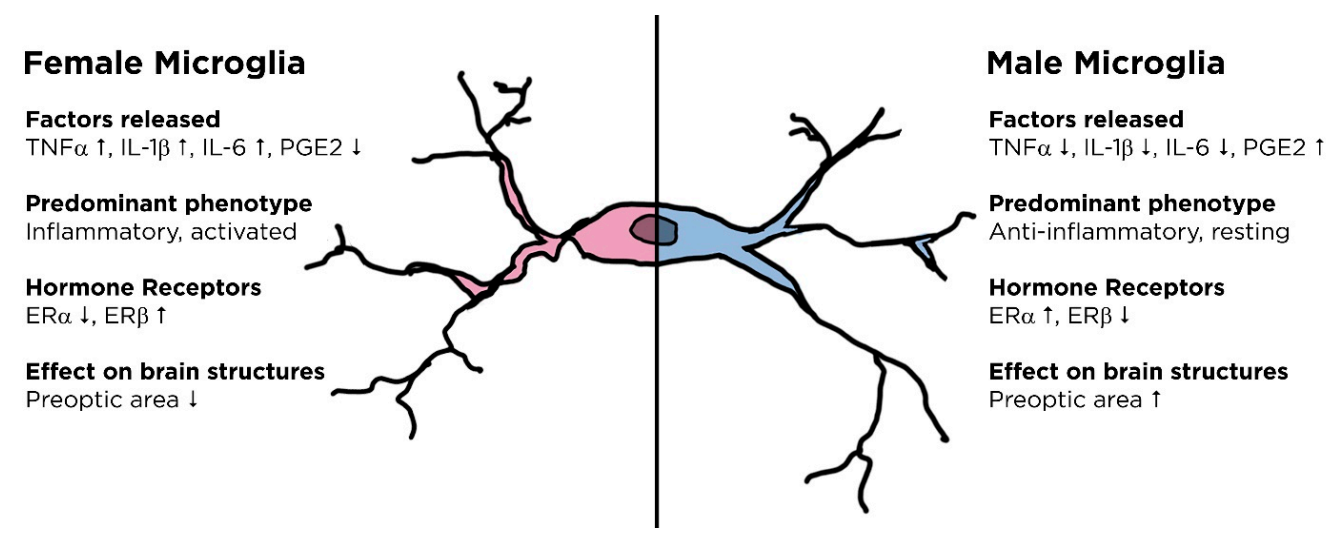

Figure 2. Gender-related disparities in microglial function. All comparisons are relative to microglia of the opposite gender. TNF $\alpha$, tumor necrosis factor alpha; PGE2, prostaglandin E2; ER, estrogen receptor.

\section{Implications in Neurodegenerative Diseases}

Neurodegenerative diseases, which include Alzheimer's disease (AD), result from a complex interplay of factors that ultimately involve the interaction of the immune system and neurons. The brains of $\mathrm{AD}$ patients are characterized by the presence of aggregated $\mathrm{A} \beta$ plaques and neurofibrillary tangles, which contribute to neuronal loss that manifests in senility and physical disability [98]. Microglia are capable of clearing these $A \beta$ aggregates through phagocytosis, although their capacity to do so is heavily determined by age and gender.

Age is a major risk factor for $\mathrm{AD}$, with the likelihood of developing this disease increasing over time [99]. Further, AD is more prevalent among women than men [100]. Pro-inflammatory conditions promote the development and progression of AD [101,102], and treatment with non-steroidal anti-inflammatory drugs (NSAIDs) not only reduces the risk of developing $\mathrm{AD}$, but also delays its onset [103]. This is possibly due to the fact that the phagocytic capacity of microglia is reduced in response to inflammatory cytokines [104], indicating that microglia committed to an inflammatory phenotype may be deleterious. Indeed, treatment of animals with minocycline, which suppresses microglial activation, significantly improves symptoms in an animal model of AD [105]. There is an age-associated impairment of phagocytosis in microglia [79], which results in further plaque accumulation. Microglia isolated from neonatal or young adult mice could effectively clear A $\beta$ aggregates, but those isolated from six-month-old mice could not. However, older microglia more readily adhered to plaques than those isolated from young animals, so it is perhaps impairment in the actual engulfment process that causes this buildup [106]. On the other hand, evidence has shown that microglia become more phagocytic under inflammatory conditions, as they must boost their capacity to clear cells that have undergone apoptosis [107]. This contradicts studies that observe impaired phagocytosis in the presence of inflammatory cytokines. It may partially be explained by the fact that under endogenous conditions microglia can phagocytose apoptotic cells within $1.5 \mathrm{~h}$, which increases to $6.3 \mathrm{~h}$ following seizure induction $[30,107]$. Thus, while microglia highly populate injury sites and can be observed to phagocytose cell debris, this process is in fact slower than during homeostasis. 
In a general sense, based on the data presented above it can be thought that female microglia are more inflammatory than male, and aged microglia are more inflammatory than those from young animals. Thus, when assessing age and gender as two parameters related to a spectrum of immune activation states, young males conceivably would have the least inflammatory immune environment, with older women having a higher propensity towards microglial activation and production of inflammatory factors. As inflammation promotes a more rapid and severe AD course, it is logical that aged women would be the most likely to develop this disease, which correlates with epidemiological data from the clinic.

\section{Conclusions}

Taken together, it is clear that there is not a "one size fits all" for microglial function. A person's age and gender can greatly impact their neuroimmune activity. As advanced age and female gender are both associated with increased chronic inflammation, these individuals are more likely to be susceptible to neurodegenerative disorders in the CNS such as AD. Further, this predominance in women is also recapitulated in several other CNS pathologies, including autoimmunity [108] and stroke [109]. Current disease therapeutics do not account for person-to-person variation in immune phenotype and function, which may account for why women tend to exhibit more rapid cognitive decline following diagnosis of $\mathrm{AD}$ [110]. Understanding how these parameters impact disease progression and recovery would bring about a whole new paradigm of age- and gender-specific therapies that could be tailored to individual patients.

Acknowledgments: I thank Stella Tsirka for her mentorship and helpful discussions in preparation of this review. This work was supported by NIH IRACDA NY-CAPS K12-GM-102778.

Conflicts of Interest: The author declares no conflicts of interest.

\section{Abbreviations}

$\begin{array}{ll}\text { AD } & \text { Alzheimer's disease } \\ \text { ATP } & \text { adenosine triphosphate } \\ \text { BBB } & \text { Blood-brain barrier } \\ \text { CNS } & \text { Central nervous system } \\ \text { CSF1R } & \text { Colony stimulating factor 1 receptor } \\ \text { DHT } & \text { Dihydrotestosterone } \\ \text { ER } & \text { Estrogen receptor } \\ \text { HSP } & \text { Heat shock protein } \\ \text { IL } & \text { Interleukin } \\ \text { iNOS } & \text { Inducible nitric oxide synthase } \\ \text { MCP1 } & \text { Monocyte chemoattractant protein 1 } \\ \text { MHC } & \text { Major histocompatibility complex } \\ \text { NO } & \text { Nitric oxide } \\ \text { NOD } & \text { Nucleotide-binding oligomerization domain-like } \\ \text { PGE2 } & \text { Prostaglandin E2 } \\ \text { POA } & \text { Preoptic area } \\ \text { PRR } & \text { Pattern recognition receptor } \\ \text { ROS } & \text { Reactive oxygen species } \\ \text { TGF } \beta & \text { Transforming growth factor beta } \\ \text { TNF } \alpha & \text { Tumor necrosis factor alpha } \\ & \end{array}$

\section{References}

1. Hanisch, U.K.; Kettenmann, H. Microglia: Active sensor and versatile effector cells in the normal and pathologic brain. Nat. Neurosci. 2007, 10, 1387-1394. [CrossRef] [PubMed]

2. Van Rossum, D.; Hanisch, U.K. Microglia. Metab. Brain Dis. 2004, 19, 393-411. [CrossRef] [PubMed] 
3. Nimmerjahn, A.; Kirchhoff, F.; Helmchen, F. Resting microglial cells are highly dynamic surveillants of brain parenchyma in vivo. Science 2005, 308, 1314-1318. [CrossRef] [PubMed]

4. Olson, J.K.; Girvin, A.M.; Miller, S.D. Direct activation of innate and antigen-presenting functions of microglia following infection with Theiler's virus. J. Virol. 2001, 75, 9780-9789. [CrossRef] [PubMed]

5. Wake, H.; Moorhouse, A.J.; Jinno, S.; Kohsaka, S.; Nabekura, J. Resting microglia directly monitor the functional state of synapses in vivo and determine the fate of ischemic terminals. J. Neurosci. 2009, 29, 3974-3980. [CrossRef] [PubMed]

6. Ji, K.; Akgul, G.; Wollmuth, L.P.; Tsirka, S.E. Microglia actively regulate the number of functional synapses. PLOS ONE 2013, 8, e56293. [CrossRef] [PubMed]

7. Paolicelli, R.C.; Bolasco, G.; Pagani, F.; Maggi, L.; Scianni, M.; Panzanelli, P.; Giustetto, M.; Ferreira, T.A.; Guiducci, E.; Dumas, L.; et al. Synaptic pruning by microglia is necessary for normal brain development. Science 2011, 333, 1456-1458. [CrossRef] [PubMed]

8. Varol, C.; Landsman, L.; Fogg, D.K.; Greenshtein, L.; Gildor, B.; Margalit, R.; Kalchenko, V.; Geissmann, F.; Jung, S. Monocytes give rise to mucosal, but not splenic, conventional dendritic cells. J. Exp. Med. 2007, 204, 171-180. [CrossRef] [PubMed]

9. Guillemin, G.J.; Brew, B.J. Microglia, macrophages, perivascular macrophages, and pericytes: A review of function and identification. J. Leukoc. Biol. 2004, 75, 388-397. [CrossRef] [PubMed]

10. Alliot, F.; Godin, I.; Pessac, B. Microglia derive from progenitors, originating from the yolk sac, and which proliferate in the brain. Brain Res. Dev. Brain Res. 1999, 117, 145-152. [CrossRef]

11. Ginhoux, F.; Greter, M.; Leboeuf, M.; Nandi, S.; See, P.; Gokhan, S.; Mehler, M.F.; Conway, S.J.; Ng, L.G.; Stanley, E.R.; et al. Fate mapping analysis reveals that adult microglia derive from primitive macrophages. Science 2010, 330, 841-845. [CrossRef] [PubMed]

12. Checchin, D.; Sennlaub, F.; Levavasseur, E.; Leduc, M.; Chemtob, S. Potential role of microglia in retinal blood vessel formation. Investig. Ophthalmol. Vis. Sci. 2006, 47, 3595-3602. [CrossRef] [PubMed]

13. Fantin, A.; Vieira, J.M.; Gestri, G.; Denti, L.; Schwarz, Q.; Prykhozhij, S.; Peri, F.; Wilson, S.W.; Ruhrberg, C. Tissue macrophages act as cellular chaperones for vascular anastomosis downstream of VEGF-mediated endothelial tip cell induction. Blood 2010, 116, 829-840. [CrossRef] [PubMed]

14. Rymo, S.F.; Gerhardt, H.; Wolfhagen Sand, F.; Lang, R.; Uv, A.; Betsholtz, C. A two-way communication between microglial cells and angiogenic sprouts regulates angiogenesis in aortic ring cultures. PLoS ONE 2011, 6, e15846. [CrossRef] [PubMed]

15. Vela, J.M.; Dalmau, I.; Gonzalez, B.; Castellano, B. Morphology and distribution of microglial cells in the young and adult mouse cerebellum. J. Comp. Neurol. 1995, 361, 602-616. [CrossRef] [PubMed]

16. Masuda, T.; Croom, D.; Hida, H.; Kirov, S.A. Capillary blood flow around microglial somata determines dynamics of microglial processes in ischemic conditions. Glia 2011, 59, 1744-1753. [CrossRef] [PubMed]

17. Ajami, B.; Bennett, J.L.; Krieger, C.; Tetzlaff, W.; Rossi, F.M. Local self-renewal can sustain CNS microglia maintenance and function throughout adult life. Nat. Neurosci. 2007, 10, 1538-1543. [CrossRef] [PubMed]

18. Elmore, M.R.; Najafi, A.R.; Koike, M.A.; Dagher, N.N.; Spangenberg, E.E.; Rice, R.A.; Kitazawa, M.; Matusow, B.; Nguyen, H.; West, B.L.; et al. Colony-stimulating factor 1 receptor signaling is necessary for microglia viability, unmasking a microglia progenitor cell in the adult brain. Neuron 2014, 82, 380-397. [CrossRef] [PubMed]

19. Chechik, G.; Meilijson, I.; Ruppin, E. Synaptic pruning in development: A computational account. Neural Comput. 1998, 10, 1759-1777. [CrossRef] [PubMed]

20. Tremblay, M.E.; Lowery, R.L.; Majewska, A.K. Microglial interactions with synapses are modulated by visual experience. PLoS Biol. 2010, 8, e1000527. [CrossRef] [PubMed]

21. Schafer, D.P.; Lehrman, E.K.; Kautzman, A.G.; Koyama, R.; Mardinly, A.R.; Yamasaki, R.; Ransohoff, R.M.; Greenberg, M.E.; Barres, B.A.; Stevens, B. Microglia sculpt postnatal neural circuits in an activity and complement-dependent manner. Neuron 2012, 74, 691-705. [CrossRef] [PubMed]

22. Stevens, B.; Allen, N.J.; Vazquez, L.E.; Howell, G.R.; Christopherson, K.S.; Nouri, N.; Micheva, K.D.; Mehalow, A.K.; Huberman, A.D.; Stafford, B.; et al. The classical complement cascade mediates CNS synapse elimination. Cell 2007, 131, 1164-1178. [CrossRef] [PubMed]

23. Chu, Y.; Jin, X.; Parada, I.; Pesic, A.; Stevens, B.; Barres, B.; Prince, D.A. Enhanced synaptic connectivity and epilepsy in C1q knockout mice. Proc. Natl. Acad Sci. USA 2010, 107, 7975-7980. [CrossRef] [PubMed] 
24. Squarzoni, P.; Oller, G.; Hoeffel, G.; Pont-Lezica, L.; Rostaing, P.; Low, D.; Bessis, A.; Ginhoux, F.; Garel, S. Microglia modulate wiring of the embryonic forebrain. Cell Rep. 2014, 8, 1271-1279. [CrossRef] [PubMed]

25. Carson, M.J.; Doose, J.M.; Melchior, B.; Schmid, C.D.; Ploix, C.C. CNS immune privilege: Hiding in plain sight. Immunol. Rev. 2006, 213, 48-65. [CrossRef] [PubMed]

26. Erblich, B.; Zhu, L.; Etgen, A.M.; Dobrenis, K.; Pollard, J.W. Absence of colony stimulation factor-1 receptor results in loss of microglia, disrupted brain development and olfactory deficits. PLoS ONE 2011, 6, e26317. [CrossRef] [PubMed]

27. Li, J.; Chen, K.; Zhu, L.; Pollard, J.W. Conditional deletion of the colony stimulating factor-1 receptor (c-fms proto-oncogene) in mice. Genesis 2006, 44, 328-335. [CrossRef] [PubMed]

28. Davalos, D.; Grutzendler, J.; Yang, G.; Kim, J.V.; Zuo, Y.; Jung, S.; Littman, D.R.; Dustin, M.L.; Gan, W.B. ATP mediates rapid microglial response to local brain injury in vivo. Nat. Neurosci. 2005, 8, 752-758. [CrossRef] [PubMed]

29. Pedersen, E.B.; McNulty, J.A.; Castro, A.J.; Fox, L.M.; Zimmer, J.; Finsen, B. Enriched immune-environment of blood-brain barrier deficient areas of normal adult rats. J. Neuroimmunol. 1997, 76, 117-131. [CrossRef]

30. Sierra, A.; Encinas, J.M.; Deudero, J.J.; Chancey, J.H.; Enikolopov, G.; Overstreet-Wadiche, L.S.; Tsirka, S.E.; Maletic-Savatic, M. Microglia shape adult hippocampal neurogenesis through apoptosis-coupled phagocytosis. Cell Stem Cell 2010, 7, 483-495. [CrossRef] [PubMed]

31. Raivich, G.; Banati, R. Brain microglia and blood-derived macrophages: Molecular profiles and functional roles in multiple sclerosis and animal models of autoimmune demyelinating disease. Brain Res. Brain Res. Rev. 2004, 46, 261-281. [CrossRef] [PubMed]

32. Kreutzberg, G.W. Microglia: A sensor for pathological events in the CNS. Trends Neurosci. 1996, 19, 312-318. [CrossRef]

33. Hanisch, U.K. Microglia as a source and target of cytokines. Glia 2002, 40, 140-155. [CrossRef] [PubMed]

34. Chao, C.C.; Hu, S.; Molitor, T.W.; Shaskan, E.G.; Peterson, P.K. Activated microglia mediate neuronal cell injury via a nitric oxide mechanism. J. Immunol. 1992, 149, 2736-2741. [PubMed]

35. Kigerl, K.A.; Gensel, J.C.; Ankeny, D.P.; Alexander, J.K.; Donnelly, D.J.; Popovich, P.G. Identification of two distinct macrophage subsets with divergent effects causing either neurotoxicity or regeneration in the injured mouse spinal cord. J. Neurosci. 2009, 29, 13435-13444. [CrossRef] [PubMed]

36. Lo, D.; Feng, L.; Li, L.; Carson, M.J.; Crowley, M.; Pauza, M.; Nguyen, A.; Reilly, C.R. Integrating innate and adaptive immunity in the whole animal. Immunol. Rev. 1999, 169, 225-239. [CrossRef] [PubMed]

37. Coyle, P.K. Dissecting the immune component of neurologic disorders: A grand challenge for the 21st century. Front. Neurol. 2011, 2, 37. [CrossRef] [PubMed]

38. Hanke, M.L.; Kielian, T. Toll-like receptors in health and disease in the brain: Mechanisms and therapeutic potential. Clin. Sci. 2011, 121, 367-387. [CrossRef] [PubMed]

39. Ravichandran, K.S. "Recruitment signals" from apoptotic cells: Invitation to a quiet meal. Cell 2003, 113, 817-820. [CrossRef]

40. Sivagnanam, V.; Zhu, X.; Schlichter, L.C. Dominance of E. coli phagocytosis over LPS in the inflammatory response of microglia. J. Neuroimmunol. 2010, 227, 111-119. [CrossRef] [PubMed]

41. Caso, J.R.; Pradillo, J.M.; Hurtado, O.; Leza, J.C.; Moro, M.A.; Lizasoain, I. Toll-like receptor 4 is involved in subacute stress-induced neuroinflammation and in the worsening of experimental stroke. Stroke 2008, 39, 1314-1320. [CrossRef] [PubMed]

42. Lehnardt, S.; Lehmann, S.; Kaul, D.; Tschimmel, K.; Hoffmann, O.; Cho, S.; Krueger, C.; Nitsch, R.; Meisel, A.; Weber, J.R. Toll-like receptor 2 mediates CNS injury in focal cerebral ischemia. J. Neuroimmunol. 2007, 190, 28-33. [CrossRef] [PubMed]

43. Lehnardt, S.; Schott, E.; Trimbuch, T.; Laubisch, D.; Krueger, C.; Wulczyn, G.; Nitsch, R.; Weber, J.R. A vicious cycle involving release of heat shock protein 60 from injured cells and activation of toll-like receptor 4 mediates neurodegeneration in the CNS. J. Neurosci. 2008, 28, 2320-2331. [CrossRef] [PubMed]

44. Biber, K.; Neumann, H.; Inoue, K.; Boddeke, H.W. Neuronal 'On' and 'Off' signals control microglia. Trends Neurosci. 2007, 30, 596-602. [CrossRef] [PubMed]

45. Zhang, J.; Shi, X.Q.; Echeverry, S.; Mogil, J.S.; de Koninck, Y.; Rivest, S. Expression of CCR2 in both resident and bone marrow-derived microglia plays a critical role in neuropathic pain. J. Neurosci. 2007, 27, 12396-12406. [CrossRef] [PubMed] 
46. Yao, Y.; Tsirka, S.E. The CCL2-CCR2 system affects the progression and clearance of intracerebral hemorrhage. Glia 2012, 60, 908-918. [CrossRef] [PubMed]

47. Sheehan, J.J.; Zhou, C.; Gravanis, I.; Rogove, A.D.; Wu, Y.P.; Bogenhagen, D.F.; Tsirka, S.E. Proteolytic activation of monocyte chemoattractant protein-1 by plasmin underlies excitotoxic neurodegeneration in mice. J. Neurosci. 2007, 27, 1738-1745. [CrossRef] [PubMed]

48. Castellano, B.; Bosch-Queralt, M.; Almolda, B.; Villacampa, N.; Gonzalez, B. Purine Signaling and Microglial Wrapping. Adv. Exp. Med. Biol. 2016, 949, 147-165. [PubMed]

49. Verkhratsky, A.; Krishtal, O.A.; Burnstock, G. Purinoceptors on neuroglia. Mol. Neurobiol. 2009, 39, $190-208$. [CrossRef] [PubMed]

50. Crain, J.M.; Nikodemova, M.; Watters, J.J. Expression of P2 nucleotide receptors varies with age and sex in murine brain microglia. J. Neuroinflamm. 2009, 6, 24. [CrossRef] [PubMed]

51. Bernardino, L.; Balosso, S.; Ravizza, T.; Marchi, N.; Ku, G.; Randle, J.C.; Malva, J.O.; Vezzani, A. Inflammatory events in hippocampal slice cultures prime neuronal susceptibility to excitotoxic injury: A crucial role of P2X7 receptor-mediated IL-1beta release. J. Neurochem. 2008, 106, 271-280. [CrossRef] [PubMed]

52. Hide, I.; Tanaka, M.; Inoue, A.; Nakajima, K.; Kohsaka, S.; Inoue, K.; Nakata, Y. Extracellular ATP triggers tumor necrosis factor-alpha release from rat microglia. J. Neurochem. 2000, 75, 965-972. [CrossRef] [PubMed]

53. Parvathenani, L.K.; Tertyshnikova, S.; Greco, C.R.; Roberts, S.B.; Robertson, B.; Posmantur, R. P2X7 mediates superoxide production in primary microglia and is up-regulated in a transgenic mouse model of Alzheimer's disease. J. Biol. Chem. 2003, 278, 13309-13317. [CrossRef] [PubMed]

54. Suzuki, T.; Hide, I.; Ido, K.; Kohsaka, S.; Inoue, K.; Nakata, Y. Production and release of neuroprotective tumor necrosis factor by P2X7 receptor-activated microglia. J. Neurosci. 2004, 24, 1-7. [CrossRef] [PubMed]

55. Drachman, D.A. Aging of the brain, entropy, and Alzheimer disease. Neurology 2006, 67, 1340-1352. [CrossRef] [PubMed]

56. Streit, W.J.; Sammons, N.W.; Kuhns, A.J.; Sparks, D.L. Dystrophic microglia in the aging human brain. Glia 2004, 45, 208-212. [CrossRef] [PubMed]

57. Ye, S.M.; Johnson, R.W. An age-related decline in interleukin-10 may contribute to the increased expression of interleukin-6 in brain of aged mice. Neuroimmunomodulation 2001, 9, 183-192. [CrossRef] [PubMed]

58. Weaver, J.D.; Huang, M.H.; Albert, M.; Harris, T.; Rowe, J.W.; Seeman, T.E. Interleukin-6 and risk of cognitive decline: MacArthur studies of successful aging. Neurology 2002, 59, 371-378. [CrossRef] [PubMed]

59. Droge, W.; Schipper, H.M. Oxidative stress and aberrant signaling in aging and cognitive decline. Aging Cell 2007, 6, 361-370. [CrossRef] [PubMed]

60. Mouton, P.R.; Long, J.M.; Lei, D.L.; Howard, V.; Jucker, M.; Calhoun, M.E.; Ingram, D.K. Age and gender effects on microglia and astrocyte numbers in brains of mice. Brain Res. 2002, 956, 30-35. [CrossRef]

61. Damani, M.R.; Zhao, L.; Fontainhas, A.M.; Amaral, J.; Fariss, R.N.; Wong, W.T. Age-related alterations in the dynamic behavior of microglia. Aging Cell 2011, 10, 263-276. [CrossRef] [PubMed]

62. Tremblay, M.E.; Zettel, M.L.; Ison, J.R.; Allen, P.D.; Majewska, A.K. Effects of aging and sensory loss on glial cells in mouse visual and auditory cortices. Glia 2012, 60, 541-558. [CrossRef] [PubMed]

63. Streit, W.J.; Xue, Q.S. The Brain's Aging Immune System. Aging Dis. 2010, 1, 254-261. [PubMed]

64. Sierra, A.; Gottfried-Blackmore, A.C.; McEwen, B.S.; Bulloch, K. Microglia derived from aging mice exhibit an altered inflammatory profile. Glia 2007, 55, 412-424. [CrossRef] [PubMed]

65. Frank, M.G.; Barrientos, R.M.; Biedenkapp, J.C.; Rudy, J.W.; Watkins, L.R.; Maier, S.F. mRNA up-regulation of MHC II and pivotal pro-inflammatory genes in normal brain aging. Neurobiol. Aging 2006, 27, 717-722. [CrossRef] [PubMed]

66. Letiembre, M.; Hao, W.; Liu, Y.; Walter, S.; Mihaljevic, I.; Rivest, S.; Hartmann, T.; Fassbender, K. Innate immune receptor expression in normal brain aging. Neuroscience 2007, 146, 248-254. [CrossRef] [PubMed]

67. Ye, S.M.; Johnson, R.W. Increased interleukin-6 expression by microglia from brain of aged mice. J. Neuroimmunol. 1999, 93, 139-148. [CrossRef]

68. Sheng, J.G.; Mrak, R.E.; Griffin, W.S. Enlarged and phagocytic, but not primed, interleukin-1 alpha-immunoreactive microglia increase with age in normal human brain. Acta Neuropathol. 1998, 95, 229-234. [CrossRef] [PubMed]

69. Norden, D.M.; Godbout, J.P. Review: Microglia of the aged brain: Primed to be activated and resistant to regulation. Neuropathol. Appl. Neurobiol. 2013, 39, 19-34. [CrossRef] [PubMed] 
70. Godbout, J.P.; Chen, J.; Abraham, J.; Richwine, A.F.; Berg, B.M.; Kelley, K.W.; Johnson, R.W. Exaggerated neuroinflammation and sickness behavior in aged mice following activation of the peripheral innate immune system. FASEB J. 2005, 19, 1329-1331. [PubMed]

71. Chen, J.; Buchanan, J.B.; Sparkman, N.L.; Godbout, J.P.; Freund, G.G.; Johnson, R.W. Neuroinflammation and disruption in working memory in aged mice after acute stimulation of the peripheral innate immune system. Brain Behav. Immun. 2008, 22, 301-311. [CrossRef] [PubMed]

72. Barrientos, R.M.; Frank, M.G.; Hein, A.M.; Higgins, E.A.; Watkins, L.R.; Rudy, J.W.; Maier, S.F. Time course of hippocampal IL-1 beta and memory consolidation impairments in aging rats following peripheral infection. Brain Behav. Immun. 2009, 23, 46-54. [CrossRef] [PubMed]

73. Goodfellow, P.N.; Lovell-Badge, R. SRY and sex determination in mammals. Annu. Rev. Genet. 1993, 27, 71-92. [CrossRef] [PubMed]

74. Reyes, F.I.; Winter, J.S.; Faiman, C. Studies on human sexual development. I. Fetal gonadal and adrenal sex steroids. J. Clin. Endocrinol. Metab. 1973, 37, 74-78. [CrossRef] [PubMed]

75. Phoenix, C.H.; Goy, R.W.; Gerall, A.A.; Young, W.C. Organizing action of prenatally administered testosterone propionate on the tissues mediating mating behavior in the female guinea pig. Endocrinology 1959, 65, 369-382. [CrossRef] [PubMed]

76. Toran-Allerand, C.D. Sex steroids and the development of the newborn mouse hypothalamus and preoptic area in vitro: Implications for sexual differentiation. Brain Res. 1976, 106, 407-412. [CrossRef]

77. Morris, J.A.; Jordan, C.L.; Breedlove, S.M. Sexual differentiation of the vertebrate nervous system. Nat. Neurosci. 2004, 7, 1034-1039. [CrossRef] [PubMed]

78. Amateau, S.K.; McCarthy, M.M. A novel mechanism of dendritic spine plasticity involving estradiol induction of prostaglandin-E2. J. Neurosci. 2002, 22, 8586-8596. [PubMed]

79. Davis, E.C.; Popper, P.; Gorski, R.A. The role of apoptosis in sexual differentiation of the rat sexually dimorphic nucleus of the preoptic area. Brain Res. 1996, 734, 10-18. [CrossRef]

80. De Vries, G.J.; Rissman, E.F.; Simerly, R.B.; Yang, L.Y.; Scordalakes, E.M.; Auger, C.J.; Swain, A.; Lovell-Badge, R.; Burgoyne, P.S.; Arnold, A.P. A model system for study of sex chromosome effects on sexually dimorphic neural and behavioral traits. J. Neurosci. 2002, 22, 9005-9014. [PubMed]

81. Gatewood, J.D.; Wills, A.; Shetty, S.; Xu, J.; Arnold, A.P.; Burgoyne, P.S.; Rissman, E.F. Sex chromosome complement and gonadal sex influence aggressive and parental behaviors in mice. J. Neurosci. 2006, 26, 2335-2342. [CrossRef] [PubMed]

82. Bianchi, I.; Lleo, A.; Gershwin, M.E.; Invernizzi, P. The $X$ chromosome and immune associated genes. J. Autoimmun. 2012, 38, J187-J192. [CrossRef] [PubMed]

83. Voskuhl, R. Sex differences in autoimmune diseases. Biol. Sex. Differ. 2011, 2, 1. [CrossRef] [PubMed]

84. Smith-Bouvier, D.L.; Divekar, A.A.; Sasidhar, M.; Du, S.; Tiwari-Woodruff, S.K.; King, J.K.; Arnold, A.P.; Singh, R.R.; Voskuhl, R.R. A role for sex chromosome complement in the female bias in autoimmune disease. J. Exp. Med. 2008, 205, 1099-1108. [CrossRef] [PubMed]

85. Schwarz, J.M.; Sholar, P.W.; Bilbo, S.D. Sex differences in microglial colonization of the developing rat brain. J. Neurochem. 2012, 120, 948-963. [CrossRef] [PubMed]

86. Amateau, S.K.; McCarthy, M.M. Induction of PGE2 by estradiol mediates developmental masculinization of sex behavior. Nat. Neurosci. 2004, 7, 643-650. [CrossRef] [PubMed]

87. Lenz, K.M.; McCarthy, M.M. Organized for sex-steroid hormones and the developing hypothalamus. Eur. J. Neurosci. 2010, 32, 2096-2104. [CrossRef] [PubMed]

88. Lenz, K.M.; Nugent, B.M.; Haliyur, R.; McCarthy, M.M. Microglia are essential to masculinization of brain and behavior. J. Neurosci. 2013, 33, 2761-2772. [CrossRef] [PubMed]

89. Crain, J.M.; Nikodemova, M.; Watters, J.J. Microglia express distinct M1 and M2 phenotypic markers in the postnatal and adult central nervous system in male and female mice. J. Neurosci. Res. 2013, 91, 1143-1151. [CrossRef] [PubMed]

90. Koizumi, S.; Ohsawa, K.; Inoue, K.; Kohsaka, S. Purinergic receptors in microglia: Functional modal shifts of microglia mediated by P2 and P1 receptors. Glia 2013, 61, 47-54. [CrossRef] [PubMed]

91. Acaz-Fonseca, E.; Duran, J.C.; Carrero, P.; Garcia-Segura, L.M.; Arevalo, M.A. Sex differences in glia reactivity after cortical brain injury. Glia 2015, 63, 1966-1981. [CrossRef] [PubMed]

92. Baker, A.E.; Brautigam, V.M.; Watters, J.J. Estrogen modulates microglial inflammatory mediator production via interactions with estrogen receptor beta. Endocrinology 2004, 145, 5021-5032. [CrossRef] [PubMed] 
93. Sierra, A.; Gottfried-Blackmore, A.; Milner, T.A.; McEwen, B.S.; Bulloch, K. Steroid hormone receptor expression and function in microglia. Glia 2008, 56, 659-674. [CrossRef] [PubMed]

94. Vegeto, E.; Bonincontro, C.; Pollio, G.; Sala, A.; Viappiani, S.; Nardi, F.; Brusadelli, A.; Viviani, B.; Ciana, P.; Maggi, A. Estrogen prevents the lipopolysaccharide-induced inflammatory response in microglia. J. Neurosci. 2001, 21, 1809-1818. [PubMed]

95. Crain, J.M.; Watters, J.J. Estrogen and P2 Purinergic Receptor Systems in Microglia: Therapeutic Targets for Neuroprotection. Open Drug Discov. J. 2010, 2, 148-167. [PubMed]

96. Crain, J.M.; Watters, J.J. Microglial P2 Purinergic Receptor and Immunomodulatory Gene Transcripts Vary By Region, Sex, and Age in the Healthy Mouse CNS. Transcr. Open Access 2015, 3, 124. [CrossRef] [PubMed]

97. Loram, L.C.; Sholar, P.W.; Taylor, F.R.; Wiesler, J.L.; Babb, J.A.; Strand, K.A.; Berkelhammer, D.; Day, H.E.; Maier, S.F.; Watkins, L.R. Sex and estradiol influence glial pro-inflammatory responses to lipopolysaccharide in rats. Psychoneuroendocrinology 2012, 37, 1688-1699. [CrossRef] [PubMed]

98. Uylings, H.B.; de Brabander, J.M. Neuronal changes in normal human aging and Alzheimer's disease. Brain Cogn. 2002, 49, 268-276. [CrossRef] [PubMed]

99. Katzman, R. Alzheimer's disease as an age-dependent disorder. Ciba Found. Symp. 1988, 134, 69-85. [PubMed]

100. Payami, H.; Zareparsi, S.; Montee, K.R.; Sexton, G.J.; Kaye, J.A.; Bird, T.D.; Yu, C.E.; Wijsman, E.M.; Heston, L.L.; Litt, M.; et al. Gender difference in apolipoprotein E-associated risk for familial Alzheimer disease: A possible clue to the higher incidence of Alzheimer disease in women. Am. J. Hum. Genet. 1996, 58, 803-811. [PubMed]

101. Griffin, W.S.; Mrak, R.E. Interleukin-1 in the genesis and progression of and risk for development of neuronal degeneration in Alzheimer's disease. J. Leukoc. Biol. 2002, 72, 233-238. [PubMed]

102. Sala, G.; Galimberti, G.; Canevari, C.; Raggi, M.E.; Isella, V.; Facheris, M.; Appollonio, I.; Ferrarese, C. Peripheral cytokine release in Alzheimer patients: Correlation with disease severity. Neurobiol. Aging 2003, 24, 909-914. [CrossRef]

103. Etminan, M.; Gill, S.; Samii, A. Effect of non-steroidal anti-inflammatory drugs on risk of Alzheimer's disease: Systematic review and meta-analysis of observational studies. BMJ 2003, 327, 128. [CrossRef] [PubMed]

104. Koenigsknecht-Talboo, J.; Landreth, G.E. Microglial phagocytosis induced by fibrillar beta-amyloid and IgGs are differentially regulated by proinflammatory cytokines. J. Neurosci. 2005, 25, 8240-8249. [CrossRef] [PubMed]

105. Fan, R.; Xu, F.; Previti, M.L.; Davis, J.; Grande, A.M.; Robinson, J.K.; Van Nostrand, W.E. Minocycline reduces microglial activation and improves behavioral deficits in a transgenic model of cerebral microvascular amyloid. J. Neurosci. 2007, 27, 3057-3063. [CrossRef] [PubMed]

106. Floden, A.M.; Combs, C.K. Microglia demonstrate age-dependent interaction with amyloid-beta fibrils. J. Alzheimers Dis. 2011, 25, 279-293. [PubMed]

107. Abiega, O.; Beccari, S.; Diaz-Aparicio, I.; Nadjar, A.; Laye, S.; Leyrolle, Q.; Gomez-Nicola, D.; Domercq, M.; Perez-Samartin, A.; Sanchez-Zafra, V.; et al. Neuronal Hyperactivity Disturbs ATP Microgradients, Impairs Microglial Motility, and Reduces Phagocytic Receptor Expression Triggering Apoptosis/Microglial Phagocytosis Uncoupling. PLoS Biol. 2016, 14, e1002466. [CrossRef] [PubMed]

108. Ngo, S.T.; Steyn, F.J.; McCombe, P.A. Gender differences in autoimmune disease. Front. Neuroendocrinol. 2014, 35, 347-369. [CrossRef] [PubMed]

109. Dotson, A.L.; Offner, H. Sex differences in the immune response to experimental stroke: Implications for translational research. J. Neurosci. Res. 2017, 95, 437-446. [CrossRef] [PubMed]

110. Lin, K.A.; Choudhury, K.R.; Rathakrishnan, B.G.; Marks, D.M.; Petrella, J.R.; Doraiswamy, P.M.; Alzheimer's Disease Neuroimaging Initiative. Marked gender differences in progression of mild cognitive impairment over 8 years. Alzheimers Dement. 2015, 1, 103-110. [CrossRef] [PubMed]

(C) 2017 by the author. Licensee MDPI, Basel, Switzerland. This article is an open access article distributed under the terms and conditions of the Creative Commons Attribution (CC BY) license (http:/ / creativecommons.org/licenses/by/4.0/). 